\title{
A Himalayan Love Story by Namita Gokhale as a Novel of Resistance by the Protagonist in Pursuit of Emancipation
}

Harshita Chhikara

Assistant Professor,

Shri Lal Nath. Hindu College

Rohtak, Haryana, India

harshita.hc18@gmail.com

Randeep Rana

Professor

Department of English and Foreign Languages

Maharishi Dayanand University

Rohtak, Haryana, India

Abstract

Love, especially unrequited love, has been the backdrop of numerous novels. A Himalayan Love Story by Namita Gokhale also has unrequited love as its central theme. This theme further helps to deconstruct the sexual confines of a woman, which helps her in her quest for identity. Namita Gokhale in the novel, A Himalayan Love Story, deals with the aforementioned theme presented in such a way that the familiar seems unfamiliar and we see it through a different lens, with a new perspective. She manoeuvers the classic theme of unrequited love into pursuit of emancipation for Parvati, the protagonist of the novel. Suppression of sexual desire often leads to mental illness. In this novel, not only Parvati suffers from mental but also a whole generation of females before her, for instance her 
mother died of mental illness. This mental illness is symbolic of subjection of women. Insanity in Parvati is suggestive of atrocities done to her by her homosexual husband and the society as well. The novel is an account of women's tenacity, endurance and unwavering spirit against all odds. The beauty of the novel lies in the celebration of sexuality on one hand and rebellion against it on the other. The paper critically examines the subjugation of Parvati leading to her mental illness and her resistance against suppression in pursuit of emancipation and identity. The paper also tries to explore the psychological workings of the female psyche, which shapes their attitude and demeanor.

\section{Introduction}

A Himalayan Love Story, written in 1996, is the third novel of Namita Gokhale. The novel is not just about survival but a lot more. The novel beautifully portrays urges and desires of a woman, who refuses to be confined by the boundaries and choked by the suppressive environment. The protagonist, Parvati, grows beyond the stereotypical image of a middle class housewife. Her character delves deep into the workings of human psyche, particularly the female psyche and how she comprehends and deals with the problems in her daily life. Namita Gokhale cleverly deals with the theme of transition from tradition to modernity and the clash between the two. The novel is the journey of the protagonist in quest for identity.

A Himalayan Love Story is not merely a love story but a story about the struggles of the protagonist, Parvati, to find true love in her life and sexual gratification by defying the culturally imposed norms by upholding her carnal needs. The novel clearly states that female desire plays a key role in the social fabric, but it is still controlled and reformed by men. A truly sexually liberated woman is a far off dream, which still needs to be realized into reality. Analysis 
A Himalayan Love Story by Namita Gokhale begins unusually, the opening sentence foreshadows that the narrative will deal in unfulfillment

"I have always recognized that I carry an emptiness inside me, though I did not at first understand it." (Gokhale, 3)

Parvati longs for sexual fulfillment throughout her life, the desire did not turn out into the way she wanted it to. She does not get to marry the person whom she fancied and on the top of it her life is doomed. She faces betrayal and other things of the similar sort in her life throughout. Parvati tells the reader about her life in the foothills of Himalayas. Her life is deprived of any good. The Kumaon Hills serve as the perfect background as Parvati is brought up just like a wild flower without any care and concern from her mother but is still beautiful and strong. She yearns for the world, which is unknown to her and explores it all by roaming freely in the mountains. She dreams of building a palace of pine cones

A sharpened pencil gave me an immense sense of satisfaction, and I used to collect the pencil shavings in a cardboard box, certain that I would someday find practical use for them...I am going to build a palace, a palace of pine cones. We can even live there. It will be warm and cozy in winter, and if I paint the cones golden everyone will think we are rich. (13)

But the childhood desire is shattered when her mother reacts to this idea with a "resounding slap.’(14)

Parvati dreams of becoming rich and leading a comfortable life cone palace. One day, she encounters a very old lady in the woods, with frightening appearance, who says You silly girl, you're young and pretty just now, but remember, soon, very soon, you'll become just like me! She further said: "I am a tree; I am not a flower anymore.” (15) 
These statements from the old woman throw light on the relevance that beauty has in the life of a woman. She is desirable as long as she is beautiful. A woman is usually admired and adored when she is beautiful. As her youth fades, her importance and worth also fades away. Parvati learns this lesson early in her life and she got ways to tackle the betrayals waiting for her in time to come

I began to have nightmares. I would wake up, trembling, drenched in sweat, and toss and turn in be until the dawn broke...The feeling of weightlessness, of failing, of hurtling through space, would overcome me and I would wake with a thud. (18)

When her mother dies of tuberculosis, Mr Hiranand Joshi, her distant uncle, brings her to Nainital to his house named "Wee Nooke." She becomes conscious of her physical self here and wants to look beautiful. She got attracted to her young Muslim history teacher, Salman

"I first saw Salman and I was dazzled by his beauty." (23)

Adolescent and vulnerable Parvati succumbs to his advances

I was caught completely unaware by the devastating bliss. Eating sweet squelchy gulab jamun, biting into a fresh fragrant apple, clambering up a khumani tree, with the blue sky above and the hard pliant branch beneath my legs pretending I was riding a horse - nothing in my meager experience of physical pleasures had ever predicted such ecstasy. As I succumbed to the rhythm of Salman's body within mine I Knew paradise. (28)

She remembers the incident after returning from the hospital and contemplates

I had left Wee Nooke a girl, I returned a woman. I realized that we had to cover our tracks very carefully for liberal as Masterji might be, he was a man of his times, and like most celibate men, a prude. He was unlikely to 
encourage a romance, leave alone a torrid affair between his niece and a young Muslim boy, however good history teacher he may have been. (29)

Later, Salman leaves for America but Parvati does not at all feels guilty about it.

Parvati befriends two boys of her school, Lalit and Mukul, and has inclination towards Mukul Nainwal. Fate and patriarchy play their part when her uncle, Mr. Joshi, marries her off to Lalit Joshi. The decision of marriage, the most important milestone in one's life, is taken by her uncle.

The year I turned twenty Masterji told me that I was to be married. He had chosen a boy for me, somebody I already knew, and obviously liked. I thought perhaps he was talking about Mukul Nainwal, who had by then moved to Allahabad for higher studies; but no, Masterji had decided that I was to be married to Mukul's best friend, Lalit Joshi... It was not that I disliked Lalit, in fact, all in all, I rather liked him. But Masterji could not be expected to understand that I was a woman, and Lalit was, in my eyes, still a boy. (31)

Her marriage fails on both physical and emotional grounds. Lalit is homosexual having a fascination for Mukul. Parvati who has once tasted bliss with Salman finds it very tough I had tasted real passion, and I could feel nothing but scorn for this farce. My young husband looked puzzled, even oppressed, and kept a stubborn, watchful distance from me. (33)

Parvati, now caught in the clutches of circumstances, falls prey to her brother-in-law "We were both lonely, our needs possessed us and we made uncompromising, and uncomplicated love." (42-43)

Lalit suddenly dies of tuberculosis, her brother in law is soon married off and Parvati gives birth to a girl child, Irra, she is abandoned by her in laws and all these circumstances drive her into madness. Her insanity is symbolic of the inhuman treatment done to her by her 
homosexual husband and the society. It is unfortunate that Parvati and her daughter Irra became a burden on Lalit's family after his death, even after she took a good care of them. Parvati, her mother and then her daughter are devoid of the love and care that they deserve throughout their lives.

\section{Conclusion}

The path trodden by Parvati is cobbled. Each new turn brings new injuries and she juggles between the circumstances. Her journey has been pessimistic and tough. Though the novel ends on a sad and melancholic note, but it still leaves the reader in fond remembrance for long. The scent of fresh wild flower, which Parvati was, stays with the reader. Parvati is a strong-headed woman, who in spite of all odds, fought against the traditional norms in establishing her identity, maintaining her individuality and fulfilling her desires. The novel $A$ Himalayan Love Story is not just a pessimistic story of unrequited love but in fact is a plea to see women as a human being having their own distinct identity, not just objects at the mercy of their male counterparts. Namita Gokhale through her writing sensitizes the reader for the rights of women and for the rights of mankind at large and become more humane towards our fellow beings. 


\section{Works Cited}

Chandra, Subhash. "Female Subjectivity and Female Empowerment in the Fiction of Namita Gokhale.” The Literary Voice. Karnataka University Press, Dharawar, 1982.

Ghanshyan, G. A. Manishrai, L. Mukta. Women Relationships and Rebellion: A Study of Namita Gokhale's Fiction. Book Enclave, Jaipur, 2013.

Gokhale, Namita. A Himalayan Love Story. Penguin India, New Delhi, 2002.

Weeks, Jeffrey. Sexuality. Routledge, London and New York, 1986, p. 39. 